\title{
301. 生分解性マイクロアクチュエータ構造体の製作プロセスの開発
}

Development of fabrication process of biodegradable microactuator

$\bigcirc$ 西村 貢一（山口大・院）

正南和幸（山口大・院）

正 佐藤 克也（山口大・院）

Kouichi NISHIMURA Yamaguchi University, Tokiwadai, Ube, Yamaguchi

Kazuyuki MINAMI

Katsuya SATO

Yamaguchi University

Yamaguchi University

Key Words. Biodegradable polymer, Electrostatic force, Microactuator, environmental protection

\section{1. 緒言}

環境保全の動きが活発化している中で, EU では RoHS 指令 により 6 物質 $\left(\mathrm{Pb}, \mathrm{Cd}, \mathrm{Hg}, \mathrm{Cr}^{6+}, \mathrm{PBB}, \mathrm{PBDE}\right)$ の製品への含有が規 制され,これらの物質を含まない代替の駆動機構の開発が急務 である.また，機械製品の場合でも,リサイクル対象外品に使わ れている各種合金元素等の溶出が, 環境に深刻な影響を及ぼ す可能性があり,これらの金属をできるだけ含まない工業製品 の創出が必要である. 一方, 静電引力を利用したアクチュエ 一タは, 構造が簡単でマイクロ化しやすく, 構造材料として誘電 体と導電体があればよいため, 使用できる材料が多種存在し, 適材適所の使用が可能である.

これらを踏まえ, 生分解性樹脂であるポリ乳酸(PLA)フィルムを 素材に静電マイクロアクチュエータの開発を行ってきた. その結 果, 製作段階でポリ乳酸に亀裂が発生する問題が生じた(1).

本研究では,これらの問題を解決して, 静電マイクロアクチュ エータを完成させるための微細加工プロセスの開発を行う. ポリ 乳酸は熱に弱いため, 熱ダメージの入らないプロセス、またアク チュエータ駆動には加工精度の高いプロセスが必要である。

\section{2.アクチュエータの構造と動作原理}

静電マイクロアクチュエータの概念図をFig.1 亿示す. 構造とし ては, シャトル電極と固定電極をある閒隔で設け, 板バネの一端 を枠に,もう一端をシャトル電極に接続している.

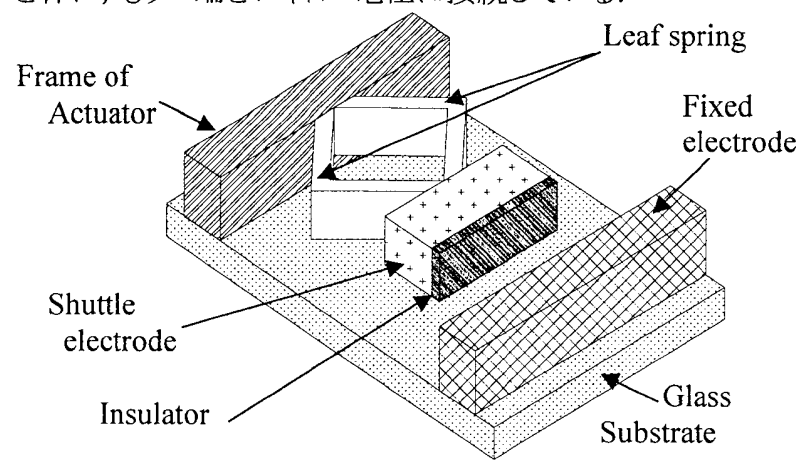

Fig1. Conceptual diagram of Microactuator

Fig.2 に静電マイクロアクチュエータの動作原理を示す. 図中 の上段は上面図を示しており，下段は側面図を示している.まず Fig.2(a)の初期状態加, シャトル電極と固定電極に電圧を印加 すると, Fig.2(b)に示すように発生した静電引力でシャトル電極が 固定電極に引き寄せられて吸着する.この際, 静電引力による 仕事が弾性エネルギーとしてバネに蓄えられる. そして, シャトル 電極と固定電極の電圧の印加を止好と, 蓄えられた弾性エネ ルギーにより, バネが元の位置に戻る.この操作を繰り返すこと により,シャトル電極が一次元の繰り返し運動を行う.

\section{3. 製作プロセス}

静電マイクロアクチュエータの製作プロセスを Fig.3 に示す. ま ず(1)で, バネ部と可動電極部を少フトオフするための犠牲層を $\mathrm{Cu}$ で製作する. 次に, (2)でポリ乳酸を基板に接着するための永久

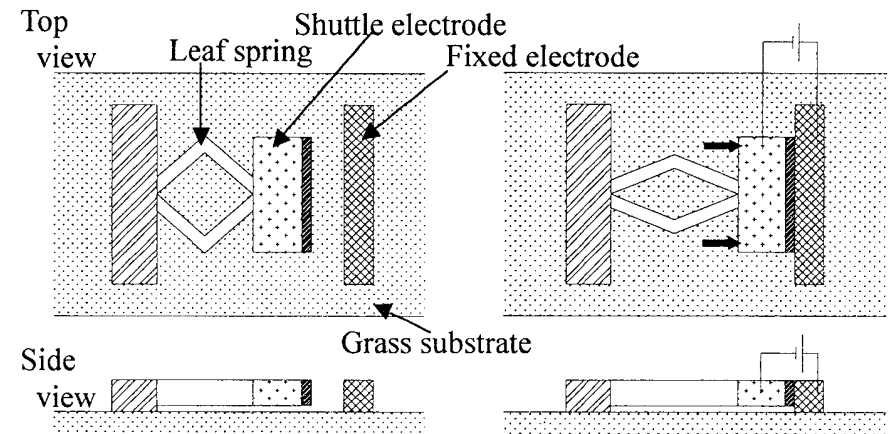

(a) Initial state

(b) Applying voltage between Shuttle and Fixed electrode Fig.2 Operational principle
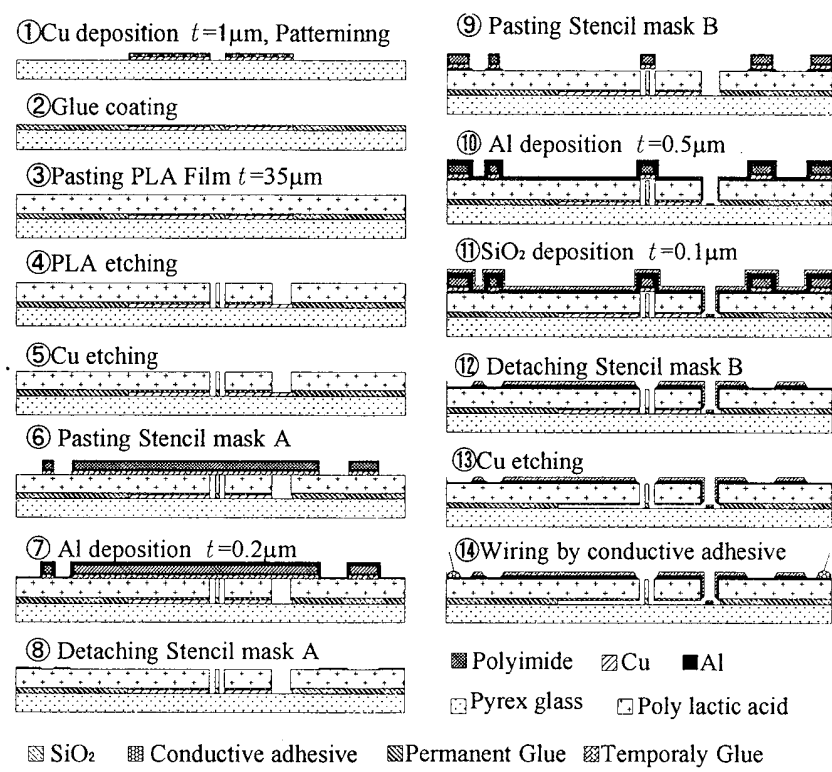

$\mathrm{SiO}_{2} \quad$ 略Conductive adhesive $\mathbb{N}$ Permanent Glue

Fig.3 Outline of fabrication process of Microactuator

接着剤を塗布し, (3)でアクチュエータを形成するポリ乳酸フィル ム(パルグリーン LC 東セロ製 厚さ $35 \mu \mathrm{m})$ を貼り付ける. その後, (4)でアクチュエータ構造を作成するために酸素 RIEを用いてポリ 乳酸のエッチングを行う.さらに(5)で配線部のショート防止のた め, 犠牲層である $\mathrm{Cu}$ の一部をエッチングする. 続いて, (6)〜 (10) で配線である Al をスパッ㚈ングにより堆積させ, (11)で絶縁体で ある $\mathrm{SiO}_{2}$ を堆積させ, (13)で $\mathrm{Cu}$ をすべてエッチングすることでアク チュエータ構造の完成となる. 最後に(16)でエナメル線を導電性 エポキシ(ドータイト D-723S)を用いて配線する.

本研究において, 製作プロセス(4)のポリ乳酸のエッチングは, 耐酸素プラズマ性を持つマスクを用いて酸素 Reactive Ion Etching(RIE)によりポリ乳酸を所望の形状に加工する.このとき 用いるマスクについて, 2 種類のマスクを検討した. Fig.4 にそれ ぞれの加エプロセスを示す. ステンシルマスク法(Fig.4 左図)で は, 仮接着剂を塗布したステンシルマスクをポリ乳酸に貼り付け, 
加工を行う.ここでステンシルマスクとは，素材にポリイミドフィル ムを用い，Alを全面に被覆して耐酸素プラズマ性を持たせたも のである.このとき 2 回エッチングを行うのは, マスク形状の制約 のために 1 回のエッチングでは所望の形状が得られないからで ある. コンフォーマルマスク法(Fig.4 右図)では, ポリ乳酸上に堆 積した $\mathrm{Al}$ を所望の形状にパターニングし,これをマスクとして用 いる方法である.この $\mathrm{Al}$ のマスクは, そのまま配線となるため, Fig.3の(6)〜8)のプロセスを省くことができる.

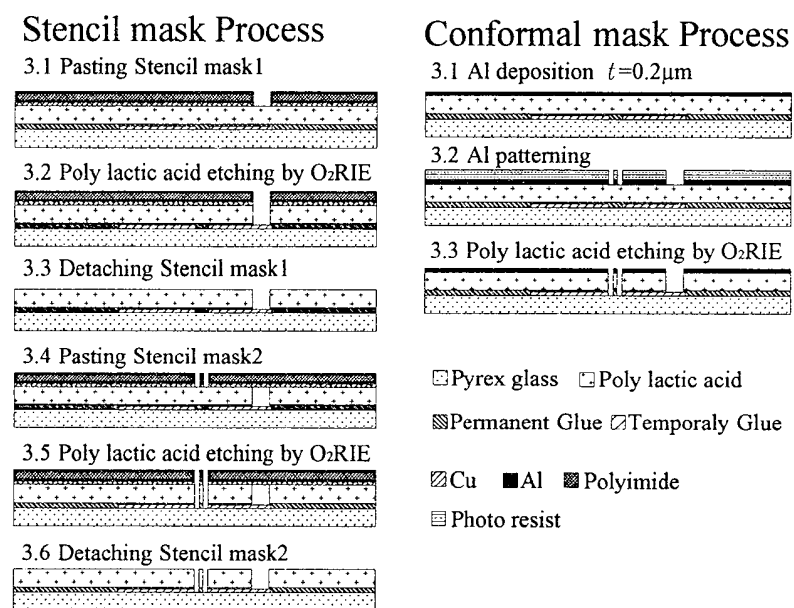

Fig.4 Two kinds of processes for poly lactic acid patterning using different masks

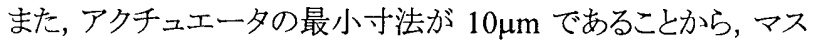
クに対する加工誤差は $1 \mu \mathrm{m}$ 以内に収まることが望まれる.

\section{4. 接着剤の選定}

本研究では, ポリ乳酸と基板の接着は永久接着剤を, ポリ乳 酸とステンシルマスクの接着は仮接着剂を, それぞれ使い分ける ため, 適用できる接着剤の選定を行った. 製作プロセス上, 仮・ 永久接着剤には以下の性能が要求される.

永久接着剤においては，製作プロセスに用いる溶剤に耐性を 持つこと, 仮接着剂においては剥離性能と接着性能の共存が求 められる.また，仮・永久接着剤それぞれが溶解する溶剂によっ て選択性が出せること, 接着対象への高い接着力と接着剤自身 がポリ乳酸に影響を与えないことも要求される.

溶剂而性試験等の結果より, 永久接着剤は, ポリ乳酸エマル ジョンミシジ油脂製, ランディPL-2000)とエアゾール接着剤(住友 3M製，スプレーのり 55)とした. ポり乳酸エマルジョンは加熱加圧 により接着を, スチレンゴムを主原料とするエアゾール接着剤は ローラーにより接着を行った. 仮接着剤には, スチレンとイソプレ ンからなる重合体を主原料とする熱可塑性エラストマー (日本ゼ オン製, SL125+QuintoneR100)とした.

\section{5. ポリ乳酸構造体の製作結果}

先で述べた製作プロセス・接着剤を用いて, ポリ乳酸のエッチ ング試験を行った. ポリ乳酸の酸素 RIE によるエッチング条件を Table.1に示す. エッチング時間は $70 \mathrm{~min} て ゙$ 行い, マスクと構造体 の梁の寸法差を加工誤差として加工精度の評価とした. それぞ れの条件で製作した構造体の光学顕微鏡写真を Fig.5 と Fig.6 に, マスクと構造体の梁の寸法を測定し, 寸法差を算出した結果 を Table. 2 に示す. Fig.5(a)には, ポリ乳酸表面に線状の亀裂が 確認できるが, Fig.5(b)では存在していないことが分かる. Fig.6 でも同様の結果となった. 永久接着剤にポリ乳酸エマルジョン を使用することで亀裂の有無に差が生じた. また, Table.2 より加 工誤差の平均值については $2 \mu \mathrm{m}$ が最小值であり, 高い加工精 度を示したが, 目標の加工誤差 $1 \mu \mathrm{m}$ は達成できていない. さら に, ばらつきが大きく, 最大で $9 \mu \mathrm{m}$ の加工誤差を生じている箇所 もあり, エッチング条件の検討が必要であるといえる.
Table.1 Oxygen RIE condition

\begin{tabular}{|c|c|}
\hline Parameter & Value \\
\hline RF power for plasma generation [W] & 200 \\
\hline Self bias voltage [V] & -300 \\
\hline Pressure [mTorr] & 30 \\
\hline Stage distance (plasma-stage) [mm] & 129.5 \\
\hline Stage temperature [ $[\mathrm{C}]$ & 0 \\
\hline $\mathrm{O}_{2}$ flow rate[standard cc/min] & 15 \\
\hline
\end{tabular}

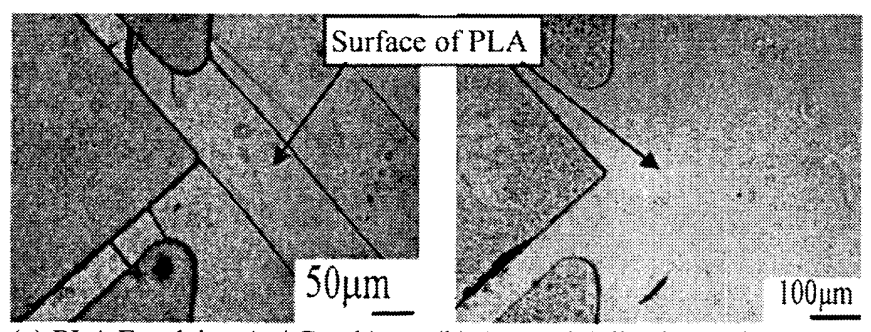

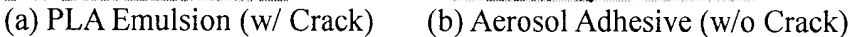
Fig.5 Photograph of specimen fabricated by using Conformal mask

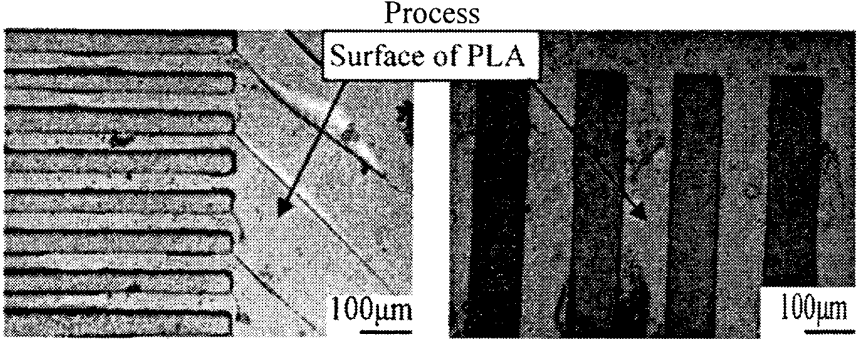

(a) PLA Emulsion (w/ Crack)

(b) Aerosol Adhesive (w/o Crack)

Fig.6 Photograph of specimen fabricated by using Stencil mask Process

Table. 2 Width error of the beam made by oxygen RIE

\begin{tabular}{|c|c|c|c|c|}
\hline \multicolumn{2}{|c|}{ Etching Condition } & \multicolumn{3}{c|}{ Width error $\mu \mathrm{m}]$} \\
\hline Mask type & Permanent glue & average & $\max$ & minimum \\
\hline \multirow{2}{*}{ Stencil mask } & PLA Emulsion & 3 & 7 & 0 \\
\cline { 2 - 5 } & Aerosol Adhesive & 2 & 6 & 0 \\
\hline $\begin{array}{c}\text { Conformal } \\
\text { mask }\end{array}$ & PLA Emulsion & 4 & 7 & 0 \\
\cline { 2 - 5 } & Aerosol Adhesive & 4 & 9 & 0 \\
\hline
\end{tabular}

さらに接着条件について検討を行った結果, 亀裂の発生は接 着条件に依存しており，亀裂方向にはフィルム依存性が存在す ることも明らかとなった。

\section{6. 結言}

(1) 酸素 RIE によるポリ乳酸のパターニングにおいて, フレキ シブルなステンシルマスクと, コンフォーマルマスクを用い る2 種類のパターニングプロセスを提案した.

(2) ポリ乳酸と基板, ポリ乳酸とステンシルマスクの接着 に適した接着剤を選定した。

(3) ポリ乳酸のエッチング試験により, 亀裂のないポリ乳酸構 造体の製作に成功し，亀裂の原因と依存性を明らかにし た。

(4) ポリ乳酸のエッチング試験の結果, マスクとポリ乳酸構造 体との寸法差は最小で $2 \mu \mathrm{m}$ と良好な結果であったが, 加 工精度は不足しているといえる. ポリ乳酸のエッチング条 件について検討が必要である.

\section{参考文献}

(1) 西村, 南, 佐藤, 日本機械学会中四国支部第 45 期総会講 謝辞 演会論文集 No.075-1 P491-492 (2007)

本研究の一部は財団法人中国電力技術研究財団の支援に より行われた。記して感謝の意を表す。 